\title{
Foreign language learning and identity reconstruction: understanding of interaction of the self
}

\section{Aprendizagem de línguas estrangeiras e reconstrução de identidade: compreensão da interação do self}

\section{Aprendizaje de lenguas extranjeras y reconstrucción de identidad: comprensión de la interacción personal}

\author{
Ameneh Nejabat ${ }^{1}$ (iD), Neda Fatehi Rad ${ }^{1}$ (iD), Massoud Tajadini ${ }^{1}$
}

${ }^{1}$ English Language Department, Kerman Branch, Islamic Azad University, Kerman, Iran.

Corresponding author:

Neda Fatehi Rad

Email: nedafatehi@yahoo.com

How to cite: Nejabat, A., Fatehi Rad, N., \& Tajadini, M. (2021). Foreign language learning and identity reconstruction: understanding of interaction of the self. Revista Tempos e Espaços em Educação, 14(33), e15923. http://dx.doi.org/10.20952/revtee.v14i33.15923

\begin{abstract}
This study focuses on the processes \& relationships between foreign language learner's identity and interaction foreign language proficiency associated with learning English in private language institutes in Iranian context, especially, participants' beliefs about languages \& participants' views about the language question are analyzed. This analysis integrates the speaker's practices and beliefs to issues of identity construction and negotiation that are observable in two contexts. Some English as a foreign language learners from 3 language institute in Tehran were picked to participate in the study, based on stratified sampling. The instrument were a 30-item likert-scale questionnaire on motivation types \& social responsibility, individual development, information medium, ... 24 likert-scale questionnaire on self-identity changes, such as, self-confidence change, subtractive change, productive change, results reveal that how language practices in human interaction display and construct identity and correlation analysis indicated that motivation types of self-identity changes and signal participant's negotiations of their own identities of these or others. Instrumental orientations related with learner's self-confidence change.
\end{abstract}

Keywords: Identity changes. Language practice. Language atitudes. EFL proficiency interaction.

\section{RESUMO}

Este estudo enfoca os processos e relações entre a identidade do aluno de língua estrangeira e a interação com a proficiência em língua estrangeira associada ao aprendizado de inglês em institutos privados de línguas no contexto iraniano, especialmente, as crenças dos participantes sobre as 
línguas e as visões dos participantes sobre a questão da língua são analisadas. Esta análise integra as práticas e crenças do falante a questões de construção e negociação de identidade que são observáveis em dois contextos. Alguns alunos de inglês como língua estrangeira de 3 institutos de idiomas em Teerã foram selecionados para participar do estudo, com base em uma amostra estratificada. $O$ instrumento foi um questionário em escala de Likert de 30 itens sobre tipos de motivação e responsabilidade social, desenvolvimento individual, meio de informação, ... 24 questionário em escala de Likert sobre mudanças de identidade, tais como mudança de autoconfiança, mudança subtrativa, produtiva mudança, os resultados revelam que como as práticas de linguagem na interação humana exibem e constroem a identidade e a análise de correlação indicou que os tipos de motivação de autoidentidade mudam e sinalizam as negociações dos participantes sobre suas próprias identidades. Orientações instrumentais relacionadas com a mudança da autoconfiança do aluno.

Palavras-chave: Mudanças de identidade. Prática linguística. Atitudes linguísticas. Interação de proficiência em inglês.

\section{RESUMEN}

Este estudio se centra en los procesos y las relaciones entre la identidad y la interacción del alumno de una lengua extranjera, el dominio de la lengua extranjera asociado con el aprendizaje del inglés en institutos de idiomas privados en el contexto iraní, especialmente, se analizan las creencias de los participantes sobre los idiomas y las opiniones de los participantes sobre la cuestión del idioma. Este análisis integra las prácticas y creencias del hablante a cuestiones de construcción y negociación de la identidad que son observables en dos contextos. Se eligió a algunos estudiantes de inglés como lengua extranjera de un instituto de 3 idiomas en Teherán para participar en el estudio, según un muestreo estratificado. El instrumento fue un cuestionario de escala Likert de 30 ítems sobre tipos de motivación y responsabilidad social, desarrollo individual, medio de información, ... Cuestionario de escala Likert de 24 sobre cambios de identidad propia, tales como, cambio de autoconfianza, cambio sustractivo, cambio, los resultados revelan que la forma en que las prácticas del lenguaje en la interacción humana muestran y construyen la identidad y el análisis de correlación indica que los tipos de motivación de la identidad propia cambian y señalan las negociaciones de los participantes de sus propias identidades de estos $u$ otros. Orientaciones instrumentales relacionadas con el cambio de autoconfianza del alumno.

Palabras clave: Cambios de identidad. Práctica del lenguaje. Actitudes lingüísticas. Interacción de dominio del inglés como lengua extranjera.

\section{INTRODUCTION}

The article of identity at the level of personal self, is chiefly eye-catching. This study investigates the extent of individual differences in SLA emphasis on social process, stay momentous. The purpose of these studies was to see if the develop proficiency in second language, they lead to change in their self identity, is the millstone of this model, Lambert (1974) arguments, "for the serious student who really masters to foreign languages in time, we have seen the possibility of a conflict of identity as he become skilled enough to become an accepted member of a new culture group". Whereas, Gardner displays, "proficiency in the language comes the possibility of changes in the learners self identity". Gardner (1985) discusses that notion of orientation toward learning and motivation and the notion of ethnocentric tendencies, will affect individual acquiring a second language fruitfully.

The research described in this paper the relationship between learner's self-identity changes and learning motivation types. On the other hand, the objective perspective concentrates on the observable aspects of social context, while the subjective perspective concentrate on individuals identity of these respect and empirical work are the benchmark of the article. For 
example a person's social identity may be determined objectively by membership in a particular group or by the characteristics of a particular social interaction, but subjectively by attitudes toward this and other groups or by perception of the social interaction (Hogg 1992, prentce et al, 1994). influences of the group on peoples self definition are examined by assessing expectations of individual in group members about each other (Swann et al., 2000).

The purpose of this investigation is to develop taxonomies of variation with foreign language learner's self identity changes, motivation types and foreign language proficiency accompanied with learning English through interaction in private language institutes in Iranian context, in addition, there has been interest in the influence of external variables of the kind investigated by sociolinguists, such as, attitude and self - confidence, were the important change among foreign language learners. There are some questions, regarding the purpose of the study.

1. What kinds of self-identity changes, do If Iranian EFL learners stand after different periods of English language learning experience?

2. Are there any critical relationships between EFL Learners' self-identity changes, motivation types, on the other hand, English language learning and interaction (i.e, English language proficiency)?

3. Are EFL learner's self-identity changes, influenced by selected demographic variables (i.e, Parent's educational status, age, Gender...).

\section{Basic Principles}

What is identity? Identity is the key tenet of the study, identity can be described as a multifaceted topics including past experiences, religion, custom, gender, age, and nationality that make up any human being identity Malouf (2000) argues that different identities, such, as social, national and religions are shaped every human being identities. The next component of identity, can be concerned with two approaches, the initial phases is important to mention that it is individual's feeling of sense, and the second concerns the way an individual perceive, grasp and represent by social context. On the other hand, the objective perspective concentrates on the social context influences these characteristics and is formed through social practices.

\section{The relationship between identity and motivation}

In most general sense, motivation concerns the direction and magnitude of human behavior and is the well known social psychological theory of language by Gardner and Lambert (1972). Gardner (1985) established social psychological conception of L2 motivation. The more general and stable aspects of motivation, such as, goal, attitude toward the activity, integrative and instrument. Integrative orientation which reflects a positive disposition toward the L2 group and desire to interact with and become similar to valued members of that community, and instrumental orientation, through language learning is primarily associated with the potential pragmatic gains of L2 proficiency. On the contrary, Norton, (2011) "explained readiness in to enter in to discourse with high level of motivation and using a L2" will not ensure proficiency in language learning, and construct of investment to complement the notion of motivation in SLA.

In continuing, according to Gardner (1985) there are two types of learning consisting of linguistic can be language proficiency and nonlinguistic which during the language construction are changed. In the cognitive psychology model, there are several perspective which differ according to the variables, include the affective factors of motivation, such as, attitude, awareness, and learner's self concept. They also an effect on other individual characteristics which may influence SLA. As Lambert's notion of learners self concept.

The final consideration that I want to highlight is, there is a convergent correlation between identity and language learning. According to Norton (2011). Most of the researchers believe the fact that language learners have fixed personalities, learning style, while, post - structural theories view 
identity as a dynamic process, fluid, and context production, so that, there seems to be integrated between language learning and identity, is a kind of claim.

A long side to the article the study of social identity is the researcher's interest. For example, a person's social identity is the result of the particular social group to which he/she belongs. Tajfel, and Turner $(1978,1979)$, focused that structural point of view can be formed by a number of key points, such as, power, prestige and other specific aspect of social context that are significantly determinants of the possibility that a person's social identity and group level.

Consequently, learning different languages is a kind of process in a longitudinal period. Social identities, and relationships with individual differences play important role in shaping the development learning of languages Huang, (2001), Hadfield and Dornyei, (2013). There is in sufficient investigation among three constructs of self - identity, motivation and L2 proficiency in the context of Iran and demonstrates the insight in relation between the factors have mentioned, as a foreign language in the context of Iran.

\section{METHODOLOGY}

The present study used a mixed study design which consisted of combination of both quantitative and qualitative approaches, the quantitative approach displayed to measure the correlation of variables under study, and qualitative approach was used to gather some detailed analysis of the main variables $\&$ present a clearer picture of contextual factors related to the main variables.

\section{Participants}

It has been studied in Iranian EFL learners at the 3 private language institutes of Tehran. Two hundred and four English language learners with different demographic features were selected as participants in the study. The demographic features relevant to study of in variables were consisted: Parent's educational status, gender, age and friendship and contact with English-speaking non-Iranians. Finally, from this population, one hundred and seventy learners provided valid data that could be used in the analyses \& were included in the final analysis, the analysis also relates the speakers' practices and beliefs to larger issues of identity construction and negotiation that are observable in the context of this community.

Table 1 represents the variability in distribution of the participants based on demographic features of age, gender \& learning English language. Around $45.3 \%$ of the participants were between fifteen to twenty years old, $40 \%$ were female and $60 \%$ male.

Table 1. Distribution of Participants' Gender, Age, and Years of Learning English ( $N=170)$

\begin{tabular}{|lcccccccccc|}
\hline \multicolumn{4}{|c}{ Gender } & \multicolumn{3}{c}{ Age } & \multicolumn{4}{c|}{ Years of Learning En } \\
\hline & $\mathrm{M}$ & $\mathrm{F}$ & $<10 \mathrm{Y}$ & $<15 \mathrm{Y}$ & $<20 \mathrm{Y}$ & $>20 \mathrm{Y}$ & $<6 \mathrm{~m}$ & $<1 \mathrm{Y}$ & $<2 \mathrm{Y}$ & $>2 \mathrm{Y}$ \\
\hline $\mathrm{N}=$ & 102 & 68 & 0 & 46 & 77 & 47 & 8 & 17 & 65 & 80 \\
$\%$ & 60.0 & 40.0 & 00.0 & 27.1 & 45.3 & 27.6 & 04.7 & 10.0 & 38.2 & 47.1 \\
\hline \multicolumn{3}{l}{ Note : M=Male, F=female, M=Month, and Y=Year } \\
\hline
\end{tabular}

Table 2 shows e variability in distribution of the participants based on demographic features of family income $\&$ parent's educational status.

The majority of the Participants were from middle class Iranian families. Around $35.9 \%$ of participants' parents had a university degree. 
Table 2. Distribution of Participants' Family income and Parent's Education Status $(N=170)$

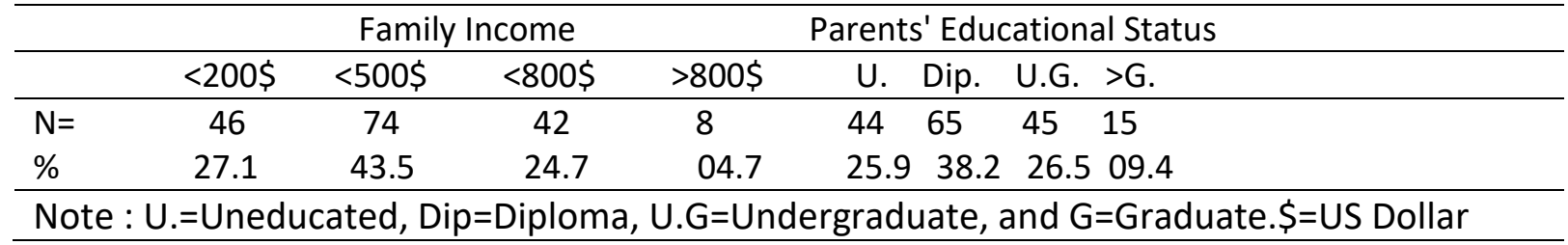

Table 2 displayed the variability in the distribution of the participants based on it on demographic features of educational status, experience of traveling abroad \& contact with non-Iranian English friends. The majority of studying in universities $\& 79.4 \%$ of them didn't have the experience of international contexts.

\section{Instruments}

Three questionnaires were used 1 . The measurement of motivation types 2 . The measurement of self-identity changes 3 . Account for variability of learners demographic features and the analysis of social media, as well as interview studied, permit for establishing two principal domain in which identity in interaction surfaces. All instruments were translated in to Persian to ensure learner's maximum comprehension of items.

\section{Measurement of motivation types}

The domain of language consists of 1anguage choice, observed or reported, code switching and language practice. Code switching \& language choice have been considered important linguistic means of negotiating identities (Ayer, Heller, code switching). In order to have in reliability and validity of data collection, a questionnaire was borrowed from Dornyei (2005)'s $L_{2}$ motivational selfsystem and all of the items were estimated using a likert scale. The reliability of this questionnaire was estimated via the analysis of Cronbach's $\alpha(\alpha=0.824, P \leq 0.05)$.

Also, marking the essential minor modifications using expert opinion, attention was also paid to construct validation of this instrument. Based on the results of factorial analysis of the data from this questionnaire done in Gao (2007), motivation types were distributed into the following seven categories.

1. Intrinsic interest, 2. Immediate achievement, 3. Going abroad, 4. Learning situation, 5. Individual development, 6 . Social responsibility, 7. Information medium:

Table 3. Summarized These Motivation Types and Related Items

\begin{tabular}{|c|c|c|}
\hline Theory/factor & Type & Number of Items \\
\hline $\begin{array}{l}\text { Integrative } \\
\text { (Gender\&Lambert,1985) }\end{array}$ & Intrinsic interest & 6 items \\
\hline $\begin{array}{l}\text { Instrumental orientation \& social status } \\
\text { (Gardner \& Lambert,1985) }\end{array}$ & $\begin{array}{l}\text { Immediate achievement } \\
\text { Information medium } \\
\text { Individual development } \\
\text { going aboard } \\
\text { Social responsibility }\end{array}$ & $\begin{array}{l}5 \text { items } \\
2 \text { items } \\
6 \text { items } \\
3 \text { items } \\
3 \text { items }\end{array}$ \\
\hline Learning situational level (Dörnyei,1994) & Learning situation & 5 items \\
\hline
\end{tabular}

Measurement of self-identity Gao (2007)'s item self-identity measure ( $a=0.751)$ was adapted used for data collection, the design of the questionnaire based on Lambert (1974).

Identity changes measured in to six categories: 1 . Self-confidance change; 2 . Additive change; 3 . Subtractive change; 4 . Productive change; 5 . Split change; 6 . Zero change.

Measurement of English language proficiency using a standardized test for the measurement of English language proficiency can be the best way. One that consists of all the skills \& subs kills 
with a different exercises $\&$ tasks. Because of the limitation of time, use only multiple choice items that are developed for an measure of proficiency. The study also faced private language $\&$ used the records of TEOFLIBT test results administrated by the institute. Interview protocol was improved to investigate self-identity changes of the participant for qualitative treatment. In this consider, based on Lambert (1974). Theory of bilingualism, a semi-structure interview protocol was developed by Yin (2011), Nunan \& Bailey (2009).

\section{Procedures}

After sampling, the participants \& some changes in the questionnaires 14 classes were identified for administration with 2 hundred and four learners as a whole number of participants. The learners were informed of the general goal of the study. Finally, 2 hundred and four copies of the questionnaire were distributed for in qualitative phase of the study, ten students were selected for the interview. Among those selected, five students satisfied with interview \& signed the consent form. They were giver a 30 minutes timer for discussion on identity change based on the semistructure interview - protocol. Each interviewee discussion was recorded \& then all of them transcribed \& made prepare for copied coding \& analysis.

\section{RESULTS}

The present analysis combines a study of spare \& Amos which consisted of five phases. First phase, descriptive analyses of self-identity changes in different categories were presented. Second phase, a series of correlational analyses to were performed to examine in the relationship between motivation types, self-identity and EFL proficiency, third phase, a canonical correlation analysis was continued to analyze the relation between motivation types \& self-identity changes and make a path model for the relationships, fourth phase, MANOVA was performed and the final step was the qualitative analysis of these-based codified interview data in to the analysis of self-identity changes identification.

\section{Illustrative Results for self-identity changes \& motivation types}

These phases were carried out in two steps. First, the means \& standard deviation of all types of self-identity changes and motivation types were estimated \& the percentages of choices of selfidentity change were presented.

Table 4. Descriptive Statistics for Motivation Types ( $N=170)$

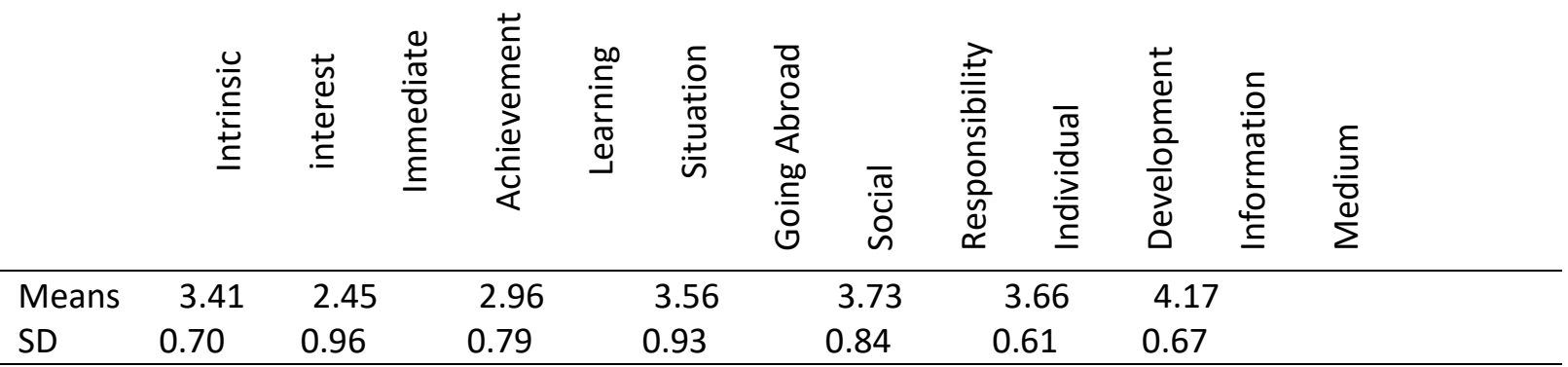

The descriptive analysis of motivation types indicated that the highest mean related to information medium ( $M=4.17)$. The second was in social responsibility $(M=3.75)$. Next, with a small difference, were individual, improvement $(M=3.66)$ and intrinsic interest $(M=3.41)$. The lowest mean belonged to learning situation $(M=2.96)$. 
Based on learner's responses, the highest means were related to the information medium, social responsibility, However the mean of intrinsic interest is high, learner's instrumental orientation was greater man their integrativeness. Therefore, the views that support the instrumental nature of FL learning in contrast to ESL context, the intrinsic interest achieved a high mean ( $M=3.41)$ among that of instrumental factors $(M=3.51)$. It displays that to portion of learners instrumental orientation and integrative or orientation were significant, immediate achievement had the lowest mean $(M=2.45)$. The descriptive statistics for self-identity changes is presented.

The total score for each kind of self-identity changes was twenty therefore, mean of twelve was considered as the cut point for changed and unchanged stated. The results revealed that the most important sent-identity change occurred in self-confidence $(M=15.12)$. The next highest in zero change $(M=15.02$ and among self-identity changes, subtractive $(M=11))$ and split $(M=9.41)$ fell behind the cut point and remained unchanged.

The ends suggested that change in FL learners self-confidence is certainly a determining factor and should be acknowledged as a non-linguistic learning result of FL learning. The outcomes indicated that the impact of change in personal identity of FL learners was greater than on their cultural identity, Although the researchers believe that limited exposure of FL culture for most of learners is attached to the mastery of FL can provide a good explanation for this type of change also FL learning had some influence on learner's cultural identity.

\section{Correlation of motivation types and self-identity changes with FL proficiency}

To have a reply for a second question of the study, a Pearson correlation test was conducted to estimate the correlation of motivation types \& self-identity changes in EFL proficiency ( $\leq 0.05)$.

Correlation measure on motivation types \& FL proficiency is displayed in Table 8. The outcome has shown a very weak relationship among three types of motivation \& FL proficiency, information medium (0.18), going abroad $(0.21)$ and social responsibility $(0.31)$. It has indicated that there is a relationship between EFL proficiency and instrumental orientation of the learners \& also there is a relationship between socially motivated among proficient foreign language learners. Also correlation estimate on self-identity change and FL proficiency is presented in Table 5.

Table 5. Pearson Correlation on Self-identity Change and FL Proficiency

\begin{tabular}{|c|c|c|c|c|c|c|c|c|}
\hline & & 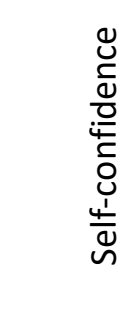 & 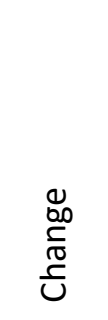 & 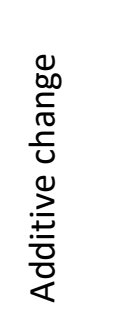 & 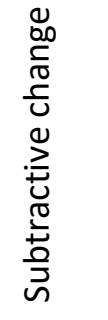 & 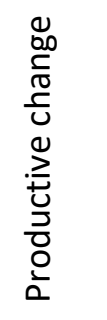 & 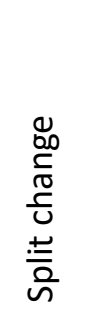 & 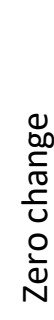 \\
\hline Proficiency & Pearson Correlation & .064 & .033 & .039. & $.211^{*}$ & .066 & $-.159^{*}$ & \\
\hline$(\mathrm{N}=170)$ & Sig.(2-tailed) & .411 & .665 & .611 & .006 & .392 & .038 & \\
\hline
\end{tabular}

It has been shown that there was a weak correlation between FL proficiency \& productive change. Also no correlations between FL proficiency \& other types of self- identity changes, outcomes show that the proficient FL learners to some extent undergo productive change. As the correlation (0.21) and the mean (13.37) indicated a positive but weak relation, it can be consisted that productive change for FL learners can be a practical goal \& is not only limited to best FL learners and this kind of change to some extent can be feasible for less proficient FL learners. 
On the other hand, to results has shown that proficient FL learners had a very low chance of undergoing zero change. So that, in a comparison, the mean of zero change (15.02) in descriptive analysis and the weak negative correlation $(-0.15)$ of zero change and there is a negative correlation between FL proficiency and zero change.

\section{Correlation of self-identity changes and motivation types}

Table 6, has shown that the Pearson correlation on self-identity change and motivation types.

Table 6. Pearson Correlation on Self-Identity Change and Motivation Types ( $N=170)$

\begin{tabular}{|c|c|c|c|c|c|c|c|}
\hline & & 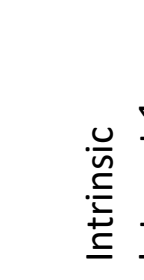 & 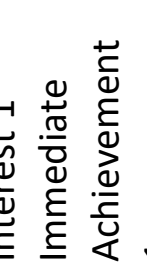 & 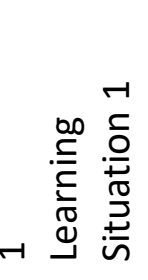 & 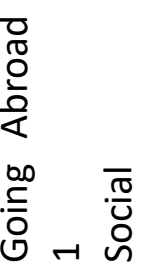 & 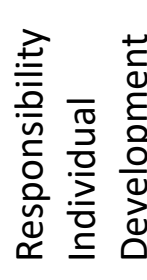 & 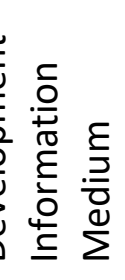 \\
\hline $\begin{array}{l}\text { Self-confidence } \\
.509 *\end{array}$ & Pearson Correlation & $.513^{*}$ & $.219 *$ & $.291^{*}$ & $.176^{*}$ & .056 & $.554^{*}$ \\
\hline $\begin{array}{l}\text { Change } \\
.000\end{array}$ & Sig.(2-tailed) & .000 & .004 & .000 & .022 & .466 & .000 \\
\hline $\begin{array}{l}\text { Addictive change } \\
.115\end{array}$ & Pearson Correlation & $.403^{*}$ & $.176^{*}$ & .83 & $.412^{*}$ & $.152 *$ & .148 \\
\hline .134 & Sig.(2-tailed) & .000 & .022 & .284 & .000 & .047 & .053 \\
\hline $\begin{array}{l}\text { Subtractive } \\
.218^{*}\end{array}$ & Pearson Correlation & $.468^{*}$ & $.437^{*}$ & $.252 *$ & $.495^{*}$ & $.175^{*}$ & $.400 *$ \\
\hline $\begin{array}{l}\text { Change } \\
.004\end{array}$ & Sig.(2-tailed) & .000 & .000 & .027 & .000 & .000 & .000 \\
\hline $\begin{array}{l}\text { Productive } \\
.027\end{array}$ & Pearson Correlation & $.349 *$ & $.274^{*}$ & $.170 *$ & $.390 *$ & $.437^{*}$ & $.291^{*}$ \\
\hline $\begin{array}{l}\text { Change } \\
.731\end{array}$ & Sig.(2-tailed) & .000 & .000 & .027 & .000 & .000 & .000 \\
\hline $\begin{array}{l}\text { Split change } \\
.276^{*}\end{array}$ & Pearson Correlation & $.546^{*}$ & $.333^{*}$ & $.287^{*}$ & $.378^{*}$ & $.167^{*}$ & $.305^{*}$ \\
\hline $\begin{array}{l}\text { Change } \\
.000\end{array}$ & Sig.(2-tailed) & .000 & .000 & .000 & .000 & .029 & .000 \\
\hline $\begin{array}{l}\text { Zero change } \\
.075\end{array}$ & Pearson Correlation & $-.168 *$ & $-.218^{*}$ & -.047 & -.115 & $-.167 *$ & $-.202 *$ \\
\hline .330 & Sig.(2-tailed) & .028 & .004 & .539 & .136 & .029 & .008 \\
\hline
\end{tabular}

The outcomes has exhibited, First, self-confidence correlated with all kinds of motivation part of social responsibility \& personal identity has an relationship with both instrumental motivation and integrative motivation, then intrinsic interest and going abroad indicated moderate correlation. Next, it can be interpreted the short term motivation types can lead to subtractive change in learners' self-identity. Among these sets of correlation only social responsibility indicated a moderate correlation and likely to undergo productive change: amazingly, zero change had a weak negative correlation with these kinds of motivation. 


\section{Canonical correlation of self-identity changes and motivation types}

There has been the relationships between self-identity relationships changes and motivation types standard correlation was performed. Canonical correlation investigated the possible relationships between two set of canonical variables. The observed variables get in touch with the six types of self-identity change \& various types of motivation.

Table 7. Multivariate Tests of Dignificance for Motivation Types and Self-identity Changes ( $n=78)$

\begin{tabular}{lccccc}
\hline Test Name & Value & Approx. F & Hypoth. DF & Error DF & Sig. of F \\
\hline Pillais & 1.36864 & 12.03725 & 28.00 & 648.00 & .000 \\
Hoteeings & 4.65683 & 26.19469 & 28.00 & 630.00 & .000 \\
\multicolumn{1}{c}{ Wilks } & .10225 & 18.10782 & 28.00 & 574.70 & .000 \\
\hline
\end{tabular}

The outcome has determined an interpretation for validity of performing a canonical correlation. 3.5. Effect of demographic variables on self-identity changes

Table12 present in multivariate test of demographic feature with self-identity changes. A series of MANOVA tests performed followed by comparing means analysis presented in bar chart to show a more comprehensible analysis of group variations among learners and the effect of them on \& learners' self-identity changes.

Table 8. Multivariate Test (MANOVA) of Demographic Features

\begin{tabular}{|c|c|c|c|c|c|c|c|}
\hline \multirow[b]{2}{*}{ Effect $^{*}$} & \multicolumn{4}{|c|}{ Hypothesis } & \multicolumn{2}{|c|}{ Noncent. } & \multirow{2}{*}{$\begin{array}{r}\text { Observed } \\
\text { Power }^{\mathrm{b}}\end{array}$} \\
\hline & Value & $\mathrm{F}$ & df $\quad$ Err & or df & Sig. & Parameter & \\
\hline Gender & .186 & $4.549^{a}$ & 6.000 & 147.000 & .000 & 27.292 & .984 \\
\hline Family income & .579 & 4.689 & 18.000 & 437.000 & .000 & 84.401 & 1.000 \\
\hline Years of English Study & .401 & 3.242 & 18.000 & 437.000 & .000 & 58.362 & 1.000 \\
\hline Educational Status & .350 & 2.835 & 18.000 & 437.000 & .000 & 51.027 & .999 \\
\hline $\begin{array}{l}\text { Parents' Educational status } \\
1.000\end{array}$ & .780 & & $311 \quad 18$ & $8.000 \quad 43$ & 37.000 & .000 & 113.602 \\
\hline Age of the participants & .232 & 2.821 & 12.000 & 292.000 & .000 & 33.858 & .986 \\
\hline I have traveled abroad & .180 & $4.406^{a}$ & 6.000 & 147.000 & .000 & 26.434 & .981 \\
\hline I have English Friend & .064 & $1.561^{\mathrm{a}}$ & 6.000 & 147.000 & .162 & 9.367 & .588 \\
\hline
\end{tabular}

*Hotelling's Trace Test, a. Exact statistic, b. Computed using alpha $=.05$

\section{DISCUSSION}

In order to have a qualitative analysis of the learners' perception \& opinion on their selfidentity changes with five participants on an half an hour and they were recorded \& transcribed interview protocol improved following the guidelines offer in Yin (2011) \& the construct of the interview was taken Goa (2007) self-identity scale estimate: a) Change in learners' self-confidence ; b) Cultural changes mediated by English-dominated; c) Cultural conflicts did exist. In response to the first (a) sentence, they had undergone self-confidence change as outcome of success or failure in learning English.

Considering self-confidence change which was high when there was no problem with learning \& when a difficulty occurred was low. It displays that learner who are sensitive to selfconfidences $\&$ therefore any change in the process of learning influence their self-confidence. On the other hand cultural change in learners, sense of identity is not unlikely, they expose to English dominated media in addition, some of them use English online, chatting with class math, it can be 
interpreted that with the spread of global media such as internet for FL learners is easier than before.

And, some of them, using \& films were their favorite, revealed that their inclination toward the cultural values behavioral patterns of $\mathrm{FL}$ and they were the main source of their attraction toward the movies, Also, learners who exposed to cultural conflicts led them to learn English, such as going to Stadium \& cultural conflict like different ceremony \& drinking win in their ceremony, however, the experience of conflict in valves and beliefs of the FL culture are not essentially negative. Therefore, changes in learners cultural values and behavioral pattern are being mediated by English.

First, the descriptive analysis displayed that, EFL learners' self-confidence \& zero change relevantly were the most prominent changes reported. The findings of this phase were in line with Dornye is model of $L_{2}$ motivation system (1994). In this model, Dornyei hypothesized that the learners' need for achievement is mediated with their sense of anxiety, self-confidence \& selfefficacy, second there was a positive relation between FL proficiency \& self-identity changes. These findings also related the significance of learners' need for self-steam hypothesized in Maslo (1995). That is highly related to the learners' experience language learning. The final phases of improving their inter language were to extent able to appreciate the cultural values \& norms of FL \& therefore had the possibility of undergoing a productive change in their cultural identity.

Third, canonical correlation Analysis displayed that language motivational system in learners repertoire \& learners, learners who had language level motivations were opened to that, learners, instrumental orientations correlated with learner's cultural identity. Another finding of correlation analysis was the relative correlation of learning situational. Fourth, the test indicated that one of the in impression of demographic feature of gender. Can be explained in the sense that male learners probably have harder ago boundaries and therefore in the process of identity change they wanted to preserve their original identity as well as accepting the cultural values of $\mathrm{Fl}$.

Fifth, the analysis of the interview data as revealed that, two principal domains in which identity interaction, the language of the discourse about the language. These two domains consistent of the organizational core of the present analysis, as both relate to the discussion o of language attitudes and speakers forming and shaping of their own identities, therefore changes in learners' cultural values \& behavioral patterns are being mediated by English dominated media.

\section{CONCLUSION}

Work on identity and language has fascinated issues considering the relationship between language and identity. sociolinguistics, and linguistic anthropology questioned in the fields of second language acquisition are developed to satisfy the need for a comprehensive theory which relate the language learner and the social world, and in both social media communication and interviews, factors of linguistic code-switching, language choice, and language practices of participant studied because they specify participants belong or not belong to a special community of practice, Also, the analysis of discourse about language related with participants, Ideas on the importance of language question, as well as their attitudes toward languages appropriate to their lives.

Identities are never autonomous but always acquire social meaning in relation to other available identity positions and others social factors (Buchotlz \& Hall nate, 2008). Thus, demonstrating how language attitudes and practices associate with the ideological positioning of the participants, identities are (re)shaped and (re)negotiated in interactions and via different linguist resources, language practices and language attitudes.

Considering pedagogical practices, four implications suggested. 1.As the outcome indicate that learners integrative and instrumental orientations have the major effect on learner's sense of 
self-confidence, teacher should use various kinds of learners, motivations to make the learners' selfconfidence in learning.

2. EFL stakeholders, particularly EFL practitioners, should be aware of the fact that nonlinguistic outcomes of learning English deserve as much attention that is paid to the EFL learners English skills and proficiency.

3. Teachers also should pay attention to the high state of learners' sensitivity to identity changes to help teachers raise their sense of self-confidence by monitoring and channeling situational needs of the learners to prevent possible negative effect on learners' identity changes.

4. EFL teachers should provide appropriate opportunities for learners to result in positive links and relations between home and foreign language cultures and cultivate learners' motivations and attitudes toward the integration of systems and culture rather than contradictions and conflicts.

\section{Authors' Contributions:}

Ameneh Nejabat: designed the study, prepared the plan, wrote the first draft of the manuscript and edited the final version. Neda Fatehi Rad: provided advice in solving problems about comparing the foundations of results and analysis the data. Massoud Tajadini: managed the literature searches and gathered theoretical foundations.

All authors read and approved the final manuscript.

Ethics Approval: Ethic committee approval from Kerman Branch, Islamic Azad University, Kerman, Iran.

Acknowledgments: The authors thanks all those who helped them in this research.

\section{REFERENCES}

Auer, P. (1998). Code-Switching in Conversation: Language, Interaction, and Identity. Routledge.

Baker, C. (1993). Foundations of bilingual education and bilingualism. Clevedon, England: Multilingual Matters.

Bucholtz, M., \& Hall, K. (2008). Finding Identity: Theory and Data. Multilingua -Journal of CrossCultural and Interlanguage Communication, 27, 151-63.

Dailey-O'Cain, J. (2017). Trans-National English in Social Media Communities. Palgrave Macmillan. Series on Language and Globalization.

Dörnyei, Z. (2005). The psychology of the language learner: Individual differences in second language acquisition. Mahwah, NJ: Lawrence Erlbaum.

Dörnyei, Z. (2009). The L2 Motivational Self System. In Dörnyei, Z., \& Ushioda, E. (eds.), Motivation, Language Identity and the L2.. Bristol: Multilingual Matters, 9-42.

Dörnyei, Z., \& Kubanyiova, M. (2014). Motivating Learners, Motivating Teachers. Building Vision in the Language Classroom. Cambridge: Cambridge University Press.

Ellemers, N., \& Barreto, M., \& Spears, R. (1999a). Commitment and strategic responses to social context, 127-46.

Gao, Y. (2007). Relationship between English learning motivation types and self-identity changes among Chinese students. TESOL Quarterly, 41(1), 133-155.

Gardner, R. C. (1985). The social psychology of language 4: The role of attitudes and motivation. Maryland: Edward Arnold. 
Heller, M. (2010). Codeswitching, Anthropological and Sociolinguistic Perspectives. Mouton de Gruyter.

Jackson, J. W. (2001). Ingroup attitudes as a function of different dimensions of group identification and perceived intergroup conflict. Self Identity. In press.

Kozachenko, I. (2017). ICT and Migration. Horizon Scanning Report, (2013), http://2plqyp1eOnbi44cllfr7pbor.wpengine.netdnacdn.com/files/2013/01/ICT-and-MigrationKozachenko.pdf. Accessed 20 Aug.

Lambert, W. E. (1974). Culture and language as factors in learning and education. In F. E. Aboud \& R. D. Meade (Eds.), Cultural factors in learning and education (91-122). Bellingham, WA: Fifth Western Washington Symposium on Learning. Mckinlay and Mcvittie.

Norris, S. (2011). Identity in (Inter) action: Introducing Multimodal (Inter) action Analysis. De Gruyter Mouton/Trends in Applied Linguistic.

Nunan, D., \& Bailey, K. M. (2009). Exploring second language classroom research: A comprehensive guide. Boston, MA: HEINLE, CENGAGE Learning.

Smith, E. R., Murphy, J., \& Coats, S. (1999). Attachment to groups: theory and measurement. J. Pres. Psychol, 94-110.

Yin, K.R. (2011). Qualitative Research from Start to Finish. NY: Guilford Press.

Yin, K. R. (2018). Code-Switching and the Politics of Language. One Speaker, Two Languages, edited by Lesley Milroy and Pieter Muysken, Cambridge UP, 158-74.

Yin, K.R. (1992). The Politics of Codeswitching and Language Choice. Journal of Multilingual and Multicultural Development, 13(1-2), 123-42.

Received: 11 May 2021 | Accepted: 2 June 2021 | Published: 22 June 2021

This is an Open Access article distributed under the terms of the Creative Commons Attribution License, which permits unrestricted use, distribution, and reproduction in any medium, provided the original work is properly cited. 